Supplementary material to

\title{
Aerosol particle measurements at three stationary sites in the megacity of Paris during summer 2009: Meteorology and air mass origin dominate aerosol particle composition and size distribution
}

F. Freutel ${ }^{1}$, J. Schneider ${ }^{1}$, F. Drewnick ${ }^{1}$, S.-L. von der Weiden-Reinmüller ${ }^{1}$, M. Crippa ${ }^{2}$, A. S. H. Prévôt ${ }^{2}$, U. Baltensperger ${ }^{2}$, L. Poulain ${ }^{3}$, A. Wiedensohler ${ }^{3}$, J. Sciare ${ }^{4}$, R. SardaEstève $^{4}$, J. F. Burkhart ${ }^{5}$, S. Eckhardt ${ }^{5}$, A. Stohl ${ }^{5}$, V. Gros ${ }^{4}$, A. Colomb ${ }^{6,7}$, V. Michoud ${ }^{6}$, J.

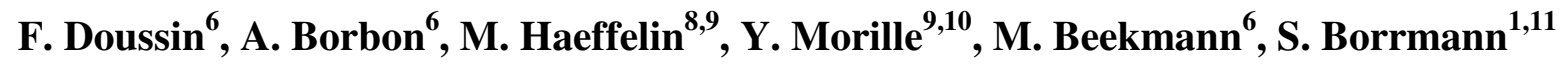

[1] Max Planck Institute for Chemistry, Mainz, Germany

[2] Paul Scherrer Institute, Villigen, Switzerland

[3] Leibniz Institute for Tropospheric Research, Leipzig, Germany

[4] Laboratoire des Sciences du Climat et de l'Environnement, Gif-sur-Yvette, France

[5] Norwegian Institute for Air Research, Kjeller, Norway

[6] LISA, UMR-CNRS 7583, Université Paris Est Créteil (UPEC), Université Paris Diderot (UPD), Créteil, France

[7] LaMP, Clermont Université, Université Blaise Pascal, CNRS, Aubière, France

[8] Institut Pierre-Simon Laplace, Paris, France

[9] Site Instrumental de Recherche par Télédétection Atmosphérique, Palaiseau, France

[10] Laboratoire de Météorologie Dynamique, Palaiseau, France

[11] Institute of Atmospheric Physics, Johannes Gutenberg University Mainz, Mainz, Germany

Correspondence to: J. Schneider (johannes.schneider@mpic.de) 
Table S1. Results from the intercomparison measurements between the gas phase and $\mathrm{BC}$ measurement instruments on-board the Mobile Laboratory (MoLa) and at the stationary sites.

\begin{tabular}{|c|c|c|c|c|c|c|}
\hline \multirow[t]{2}{*}{$\begin{array}{c}\text { Parameter } \\
\text { Sub NE }\end{array}$} & \multirow[t]{2}{*}{ Slope $^{a}$} & \multirow[t]{2}{*}{$\begin{array}{c}\text { Pearson's } \\
\mathbf{R}^{2}\end{array}$} & \multicolumn{2}{|c|}{$\begin{array}{c}\text { Average volume mixing } \\
\text { ratio / ppb } \\
\text { or average mass } \\
\text { concentration / } \mu \mathbf{g ~ m}^{-3}\end{array}$} & \multicolumn{2}{|c|}{$\begin{array}{l}\text { Relative deviation } \\
\text { between the instruments } \\
\text { determined from: }\end{array}$} \\
\hline & & & MoLa & Sub NE & average & slope \\
\hline $\mathrm{NO}_{\mathrm{x}}$ & 1.06 & 0.96 & 11 & 10 & $10 \%$ & $6 \%$ \\
\hline $\mathrm{O}_{3}$ & 1.00 & 0.96 & 26 & 26 & $0 \%$ & $0 \%$ \\
\hline $\mathrm{BC}$ & 1.04 & 0.97 & 1.19 & 1.15 & $3 \%$ & $4 \%$ \\
\hline Downtown & & & MoLa & Downtown & average & slope \\
\hline $\mathrm{NO}_{\mathrm{x}}$ & 0.80 & 0.80 & 9 & 12 & $25 \%$ & $20 \%$ \\
\hline $\mathrm{O}_{3}$ & 0.94 & 0.93 & 26 & 27 & $4 \%$ & $6 \%$ \\
\hline $\mathrm{BC}$ & 1.01 & 0.73 & 0.86 & 0.87 & $1 \%$ & $1 \%$ \\
\hline Sub SW & & & MoLa & Sub SW & average & slope \\
\hline $\mathrm{NO}_{\mathrm{x}}$ & 0.80 & 0.48 & 4 & 5 & $20 \%$ & $20 \%$ \\
\hline $\mathrm{O}_{3}$ & 1.09 & 0.91 & 33 & 30 & $10 \%$ & $9 \%$ \\
\hline $\mathrm{BC}^{\mathrm{c}}$ & 0.72 & 0.95 & 0.32 & 0.47 & $32 \%$ & $28 \%$ \\
\hline
\end{tabular}

${ }^{\mathrm{a}}$ Linear fit forced through zero for MoLa instrument versus the instrument at the respective site (15 min averages of the time series)

${ }^{c}$ Linear fit for 1 hour averages 
Table S2. Results from the intercomparison measurements between the different counting and sizing instruments on-board the Mobile Laboratory MoLa and at Sub NE. For the UV-APS, intercomparison results are shown for the whole measured size range, and for the size range of particles with $d_{c a}>750 \mathrm{~nm}$ only. Only the latter size range is used in the further analysis due to these intercomparison results (see Sect. 2.2.1 in the main text).

\begin{tabular}{|c|c|c|c|c|c|c|}
\hline \multirow{2}{*}{$\begin{array}{c}\text { Parameter } \\
\text { Sub NE }\end{array}$} & \multirow[t]{2}{*}{ Slope $^{\mathrm{a}}$} & \multirow[t]{2}{*}{$\begin{array}{l}\text { Pearson's } \\
\mathbf{R}^{2}\end{array}$} & \multicolumn{2}{|c|}{$\begin{array}{l}\text { Average number } \\
\text { concentration } / \mathrm{cm}^{-3}\end{array}$} & \multicolumn{2}{|c|}{$\begin{array}{c}\text { Relative deviation between } \\
\text { the instruments } \\
\text { determined from: }\end{array}$} \\
\hline & & & MoLa & Sub NE & $\begin{array}{c}\text { average number } \\
\text { concentration }\end{array}$ & slope \\
\hline $\mathrm{CPC}^{\mathrm{b}}$ & 1.27 & 0.96 & 15193 & 11978 & $27 \%$ & $27 \%$ \\
\hline \multicolumn{7}{|l|}{ OPC: } \\
\hline $\begin{array}{l}\text { total number } \\
\text { concentration }\end{array}$ & 1.09 & 0.99 & 96 & 87 & $10 \%$ & $9 \%$ \\
\hline $\begin{array}{l}\text { number } \\
\text { concentration } \\
\text { per channel }\end{array}$ & 1.06 & 0.9996 & 2.9 & 2.8 & $4 \%$ & $6 \%$ \\
\hline \multicolumn{7}{|c|}{ (UV-)APS, comparison of number concentrations including all measured sizes: } \\
\hline $\begin{array}{l}\text { total number } \\
\text { concentration }\end{array}$ & 1.80 & 0.88 & 13.7 & 7.4 & $85 \%$ & $80 \%$ \\
\hline $\begin{array}{l}\text { number } \\
\text { concentration } \\
\text { per channel }\end{array}$ & 1.57 & 0.80 & 8.4 & 4.5 & $87 \%$ & $57 \%$ \\
\hline \multicolumn{7}{|c|}{ (UV-)APS, comparison only of number concentrations of particles with $d_{c a}>750 \mathrm{~nm}$ : } \\
\hline $\begin{array}{l}\text { total number } \\
\text { concentration }\end{array}$ & 1.08 & 0.91 & 2.9 & 2.4 & $21 \%$ & $8 \%$ \\
\hline $\begin{array}{l}\text { number } \\
\text { concentration } \\
\text { per channel }\end{array}$ & 1.20 & 0.99 & 2.0 & 1.7 & $18 \%$ & $20 \%$ \\
\hline \multicolumn{7}{|c|}{ FMPS / EAS (4.86 - $486 \mathrm{~nm})$ : } \\
\hline $\begin{array}{l}\text { total number } \\
\text { concentration }\end{array}$ & 0.73 & 0.88 & 10985 & 14917 & $26 \%$ & $27 \%$ \\
\hline $\begin{array}{l}\text { total number } \\
\text { concentration } \\
\text { above } 20 \mathrm{~nm}\end{array}$ & 0.86 & 0.93 & 7933 & 9080 & $13 \%$ & $14 \%$ \\
\hline
\end{tabular}

${ }^{\mathrm{a}}$ Linear fit forced through zero for correlation of the MoLa instrument versus the instrument at the Sub NE site (15 min averages of the time series ["total number concentration"], and averages of size distributions over the whole intercomparison period ["number concentration per channel"], respectively)

bote the different lower size cut-offs of the CPCs: MoLa: $2.5 \mathrm{~nm}$, Sub NE: $4.5 \mathrm{~nm}$ 
Table S3. Results from the intercomparison measurements between the different AMSs (prior to applying any scaling factors). Chloride is not included due to negligible mass concentrations.

\begin{tabular}{|c|c|c|c|c|c|c|c|}
\hline \multirow{2}{*}{$\begin{array}{l}\text { Parameter } \\
\text { Sub NE }\end{array}$} & \multirow[t]{2}{*}{ Slope $^{a}$} & \multirow[t]{2}{*}{$\begin{array}{c}\text { Pearson's } \\
\mathbf{R}^{\mathbf{2}}\end{array}$} & \multicolumn{2}{|c|}{$\begin{array}{c}\text { Average mass } \\
\text { concentration } \\
\qquad / \mu \mathrm{g} \mathrm{m}^{-3}\end{array}$} & \multicolumn{2}{|c|}{$\begin{array}{l}\text { Relative deviation } \\
\text { between the } \\
\text { instruments } \\
\text { determined from: }\end{array}$} & \multirow[t]{2}{*}{$\begin{array}{l}\text { Scaling } \\
\text { factor }\end{array}$} \\
\hline & & & MoLa $^{b}$ & Sub NE & mass & slope & \\
\hline Organics & 1.50 & 0.90 & 2.97 & 2.29 & $30 \%$ & $50 \%$ & 1.5 \\
\hline Nitrate & 1.16 & 0.83 & 0.24 & 0.21 & $14 \%$ & $16 \%$ & -- \\
\hline Sulphate & 1.11 & 0.82 & 1.36 & 1.13 & $20 \%$ & $11 \%$ & -- \\
\hline Ammonium & 1.01 & 0.84 & 0.50 & 0.47 & $6 \%$ & $1 \%$ & -- \\
\hline Downtown & & & MoLa & Downtown & mass & slope & \\
\hline Organics & 1.04 & 0.81 & 1.82 & 1.73 & $5 \%$ & $4 \%$ & -- \\
\hline Nitrate & 0.88 & 0.36 & 0.14 & 0.15 & $7 \%$ & $12 \%$ & -- \\
\hline Sulphate & 1.05 & 0.81 & 0.81 & 0.77 & $5 \%$ & $5 \%$ & -- \\
\hline Ammonium & 0.61 & 0.65 & 0.23 & 0.38 & $39 \%$ & $39 \%$ & -- \\
\hline Sub SW & & & MoLa & Sub SW & mass & slope & \\
\hline Organics & 1.29 & 0.73 & 1.00 & 0.77 & $30 \%$ & $29 \%$ & 1.3 \\
\hline Nitrate & 1.27 & 0.37 & 0.07 & 0.05 & $40 \%$ & $27 \%$ & 1.3 \\
\hline Sulphate & 1.18 & 0.91 & 0.42 & 0.35 & $20 \%$ & $18 \%$ & 1.3 \\
\hline Ammonium & 1.54 & 0.27 & 0.15 & 0.09 & $67 \%$ & $54 \%$ & 1.3 \\
\hline
\end{tabular}

${ }^{\mathrm{a}}$ Linear fit forced through zero for Mobile Laboratory AMS data versus AMS data of the respective site (15 min averages of the time series)

${ }^{\mathrm{b}}$ Mobile Laboratory

Table S4. Input data treatment and PMF analysis details for the different datasets.

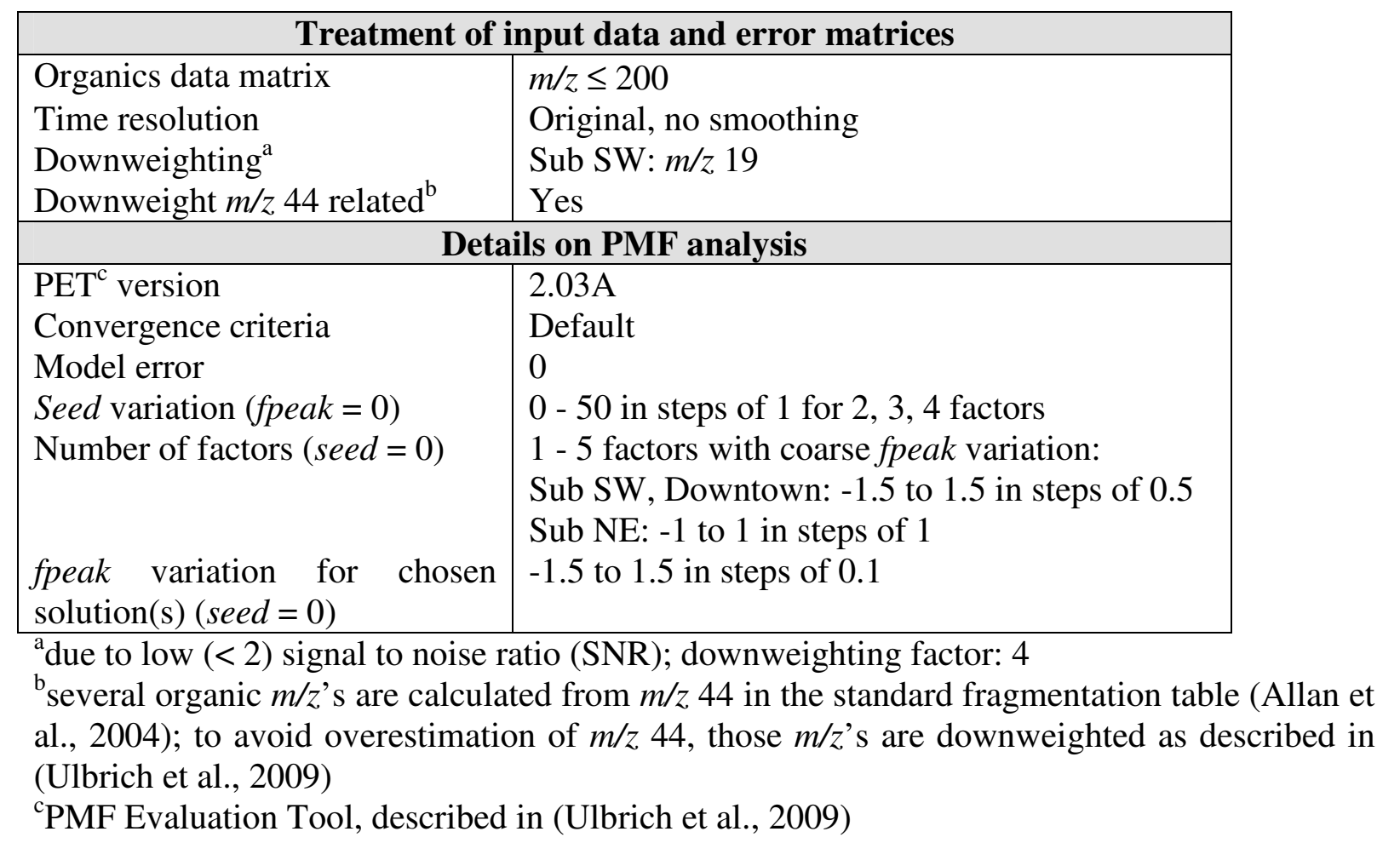


Table S5. Estimated uncertainties (from seed and fpeak variation) of retrieved mass spectra (MS) and time series (TS) for the chosen PMF solutions.

\begin{tabular}{|l|r|r|r|r|r|r|r|r|}
\hline \multirow{3}{*}{ Seed variation } & \multicolumn{2}{|c|}{$\begin{array}{c}\text { Sub SW } \\
\text { 2 factors }\end{array}$} & \multicolumn{2}{c|}{$\begin{array}{c}\text { Downtown } \\
\text { 2 factors }\end{array}$} & \multicolumn{2}{c|}{$\begin{array}{c}\text { Downtown } \\
\text { 3 factors }\end{array}$} & \multicolumn{2}{c|}{$\begin{array}{c}\text { Sub NE } \\
\text { 2 factors } \\
\end{array}$} \\
& MS & TS & MS & TS & MS & TS & MS & TS \\
\hline OOA & $0.02 \%$ & $0.1 \%$ & $0.1 \%$ & $0.4 \%$ & $0.7 \%$ & $1.2 \%$ & $0.02 \%$ & $0.2 \%$ \\
HOA & $0.13 \%$ & $0.1 \%$ & $0.1 \%$ & $0.4 \%$ & & & $0.06 \%$ & $0.1 \%$ \\
HOA $_{\text {traffic_rel. }}$ & & & & & $1.9 \%$ & $4.2 \%$ & & \\
HOA $_{\text {cooking_rel. }}$ & & & & & $0.3 \%$ & $1.8 \%$ & & \\
Fpeak variation & & & & & & & & \\
OOA & $9.9 \%$ & $8.7 \%$ & $10.6 \%$ & $18.8 \%$ & $10.8 \%$ & $18.0 \%$ & $9.6 \%$ & $12.0 \%$ \\
HOA & $9.4 \%$ & $17.4 \%$ & $12.7 \%$ & $20.3 \%$ & & & $3.9 \%$ & $18.1 \%$ \\
HOA $_{\text {traffic_rel. }}$ & & & & & $24.0 \%$ & $25.7 \%$ & & \\
HOA $_{\text {cooking_rel. }}$ & & & & & $13.0 \%$ & $37.7 \%$ & & \\
\hline
\end{tabular}

Table S6. Pearson's $\mathrm{R}^{2}$ for linear correlations of time series (15 min averages) of the selected factors from the stationary measurement sites with time series of external tracers (measured at the respective measurement site). For each solution, the best correlation to the respective tracer is highlighted in bold. The classification of the factors to HOA and OOA is also given (see main text).

\begin{tabular}{|l|r|r|r|r|r|}
\hline & \multicolumn{1}{|c|}{$\mathbf{S O}_{4}$} & \multicolumn{1}{c|}{$\mathbf{N O}_{\mathbf{3}}$} & $\mathbf{N O}_{\mathbf{x}}$ & $\mathbf{B C}$ & Classification \\
\hline Sub SW & & & & & \\
Factor 1 & 0.08 & 0.11 & $\mathbf{0 . 2 9}$ & $\mathbf{0 . 2 6}$ & HOA \\
Factor 2 & $\mathbf{0 . 5 4}$ & $\mathbf{0 . 3 5}$ & 0.06 & 0.06 & OOA \\
Downtown, 2-factor solution & & & HOA \\
Factor 1 & $<0.01$ & 0.04 & $\mathbf{0 . 2 6}$ & $\mathbf{0 . 3 6}$ & OOA \\
Factor 2 & $\mathbf{0 . 4 7}$ & $\mathbf{0 . 1 9}$ & 0.02 & 0.14 & \\
Downtown, 3-factor solution & & & O. \\
Factor 1 & $<0.01$ & 0.02 & 0.08 & 0.15 & HOA $_{\text {cooking_rel. }}$ \\
Factor 2 & $\mathbf{0 . 4 7}$ & $\mathbf{0 . 2 0}$ & 0.04 & 0.17 & OOA \\
Factor 3 & 0.03 & 0.18 & $\mathbf{0 . 5 5}$ & $\mathbf{0 . 7 2}$ & HOA $_{\text {traffic_rel. }}$ \\
Sub NE & & & & & \\
Factor 1 & 0.02 & 0.05 & $\mathbf{0 . 0 9}$ & $\mathbf{0 . 2 7}$ & HOA \\
Factor 2 & $\mathbf{0 . 5 7}$ & $\mathbf{0 . 2 6}$ & 0.01 & 0.12 & OOA \\
\hline
\end{tabular}


Table S7. Pearson's $\mathrm{R}^{2}$ values for linear correlations of factor mass spectra from the selected PMF solutions for all stationary sites with literature mass spectra [ ${ }^{\mathrm{a}}$ (Ulbrich et al., 2009); ${ }^{b}$ average of COA (cooking-related organic aerosol) source mass spectra in (He et al., 2010); caverage of COA factor mass spectra in (Allan et al., 2010)]. Marked in bold are the best correlations with each reference mass spectrum. For all correlations, $m / z$ 's 17,18 , and 28 were not regarded as they are calculated from $\mathrm{m} / \mathrm{z}, 44$ differently in different fragmentation tables used (Allan et al., 2004; Aiken et al., 2008). LV-OOA: low-volatile OOA; SV-OOA: semi-volatile OOA.

\begin{tabular}{|l|r|r|r|r|r|}
\hline & HOA $^{\mathbf{a}}$ & $\mathbf{L V}^{-}-\mathbf{O O A}^{\mathbf{a}}$ & $\mathbf{S V}^{-} \mathbf{O O A}^{\mathbf{a}}$ & $\mathbf{C O A}^{\mathbf{b}}$ & $\mathbf{C O A}^{\mathbf{c}}$ \\
\hline Sub SW & & & & & \\
Factor 1 & $\mathbf{0 . 9 7}$ & 0.38 & 0.61 & $\mathbf{0 . 8 6}$ & $\mathbf{0 . 9 0}$ \\
Factor 2 & 0.42 & $\mathbf{0 . 9 5}$ & $\mathbf{0 . 6 7}$ & 0.30 & 0.35 \\
Downtown, 2-factor solution & & & & \\
Factor 1 & $\mathbf{0 . 7 8}$ & 0.69 & $\mathbf{0 . 6 4}$ & $\mathbf{0 . 7 2}$ & $\mathbf{0 . 8 6}$ \\
Factor 2 & 0.21 & $\mathbf{0 . 8 5}$ & 0.53 & 0.14 & 0.17 \\
Downtown, 3-factor solution & & & & \\
Factor 1 & 0.66 & 0.72 & 0.54 & 0.64 & 0.81 \\
Factor 2 & 0.15 & $\mathbf{0 . 8 1}$ & 0.48 & 0.10 & 0.12 \\
Factor 3 & $\mathbf{0 . 9 3}$ & 0.43 & $\mathbf{0 . 6 9}$ & $\mathbf{0 . 8 0}$ & $\mathbf{0 . 8 4}$ \\
Sub NE & & & & & \\
Factor 1 & $\mathbf{0 . 8 7}$ & 0.58 & 0.59 & $\mathbf{0 . 7 8}$ & $\mathbf{0 . 9 2}$ \\
Factor 2 & 0.28 & $\mathbf{0 . 9 0}$ & $\mathbf{0 . 6 0}$ & 0.18 & 0.21 \\
\hline
\end{tabular}

Table S8. Comparisons of average contribution of HOA to the sum of HOA and OOA from intercomparison measurements between the Mobile Laboratory MoLa and the stationary sites: linear correlations (MoLa vs Stationary, $15 \mathrm{~min}$ averages), and average contribution calculated from average HOA and OOA mass concentrations during the whole intercomparison period.

\begin{tabular}{|l|r|r|r|r|r|r|}
\hline & Slope $^{\text {a }}$ & $\begin{array}{c}\text { Pearson's } \\
\mathbf{R}^{\mathbf{2}}\end{array}$ & \multicolumn{2}{|c|}{$\begin{array}{c}\text { Average relative HOA } \\
\text { contribution to (HOA + OOA) }\end{array}$} & \multicolumn{2}{c|}{$\begin{array}{c}\text { Relative deviation } \\
\text { determined from: }\end{array}$} \\
\hline Stationary & & & MoLa & Stationary & mass & \multicolumn{1}{c|}{ slope } \\
Sub NE & 0.93 & 0.88 & $52.7 \%$ & $48.0 \%$ & $5 \%$ & $7 \%$ \\
Downtown & 0.93 & 0.70 & $59.6 \%$ & $62.1 \%$ & $3 \%$ & $7 \%$ \\
Sub SW & 1.12 & 0.71 & $34.0 \%$ & $38.0 \%$ & $4 \%$ & $12 \%$ \\
\hline
\end{tabular}

${ }^{\mathrm{a}}$ Linear fit forced through zero for MoLa AMS data versus AMS data of the respective site 

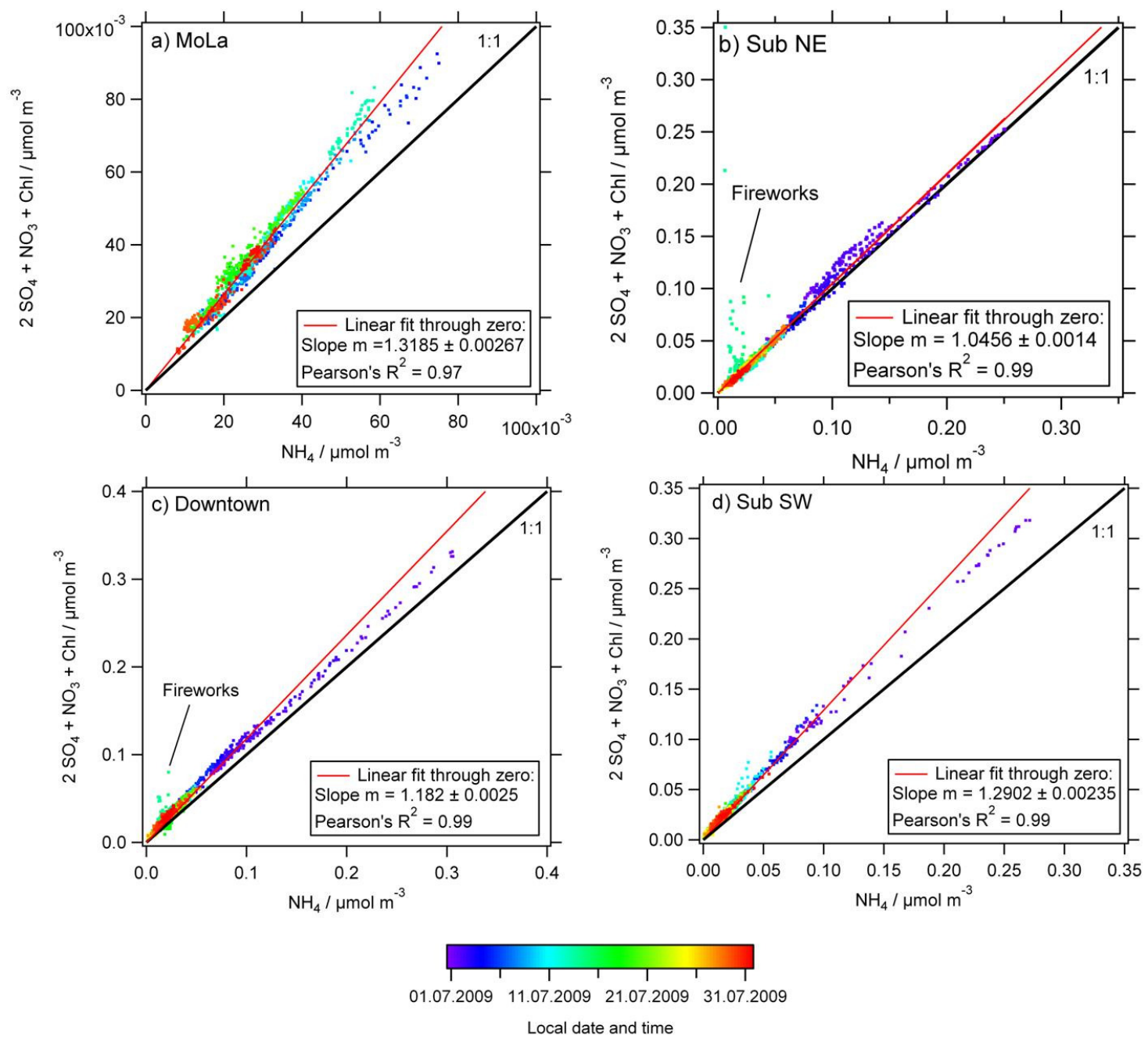

Figure S1. Acidity plots for stationary measurements of the Mobile Laboratory MoLa (a) and the different stationary sites (b-d). Plotted are the molar concentrations of $\mathrm{NO}_{3}+2 \mathrm{SO}_{4}+\mathrm{Chl}$ (i.e. the calculated, theoretical molar concentration of $\mathrm{NH}_{4}$ needed for complete neutralization) versus the measured molar concentration of $\mathrm{NH}_{4}$. A slope of one indicates completely neutralized aerosol, larger than one acidic aerosol, smaller than one basic aerosol. Data shown are averaged over $15 \mathrm{~min}$. Time periods being affected by the fireworks around July 14 are not included for the linear fits. The colourcoding indicates local date and time. 

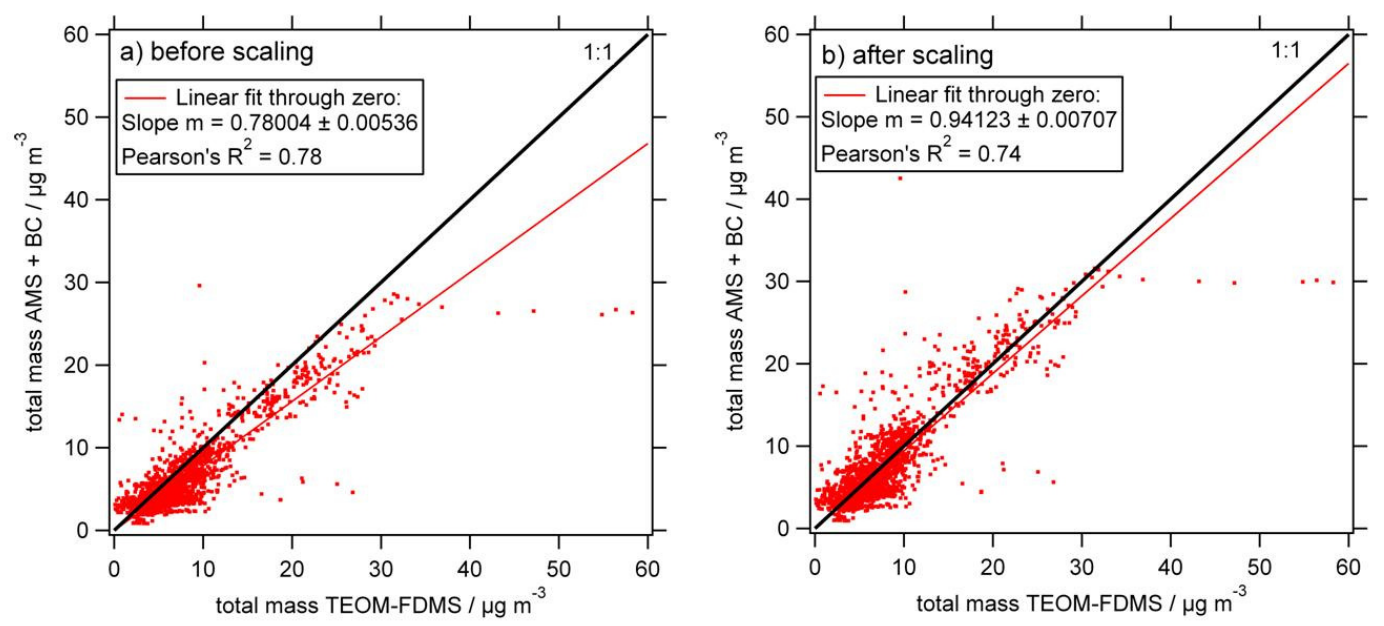

Figure S2. Total aerosol mass concentration of BC plus AMS species versus the measured total aerosol mass concentration by TEOM-FDMS measured in $\mathrm{PM}_{1}$ at Sub NE before (left) and after (right) the scaling of the organics by a factor of 1.5. Data shown are averaged over 15 min.
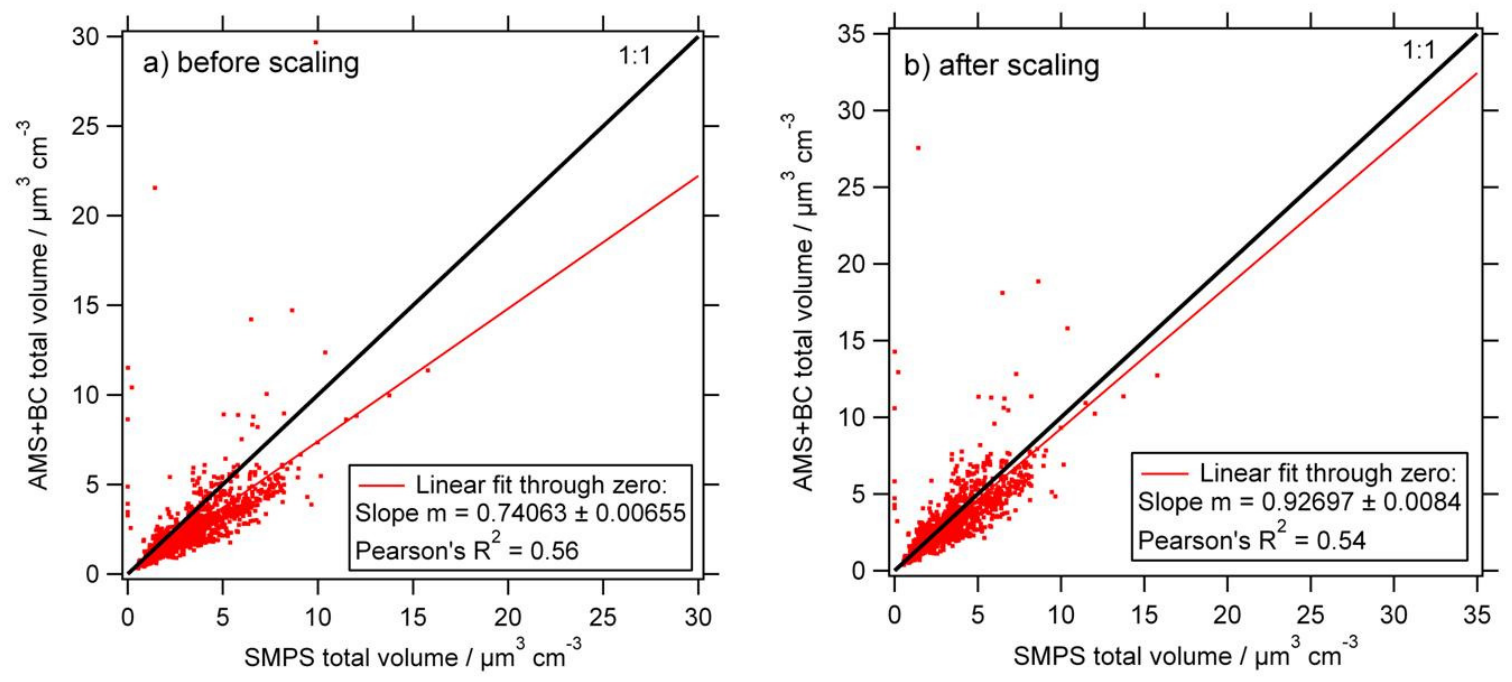

Figure S3. Total particle volume concentration of BC plus AMS species (calculated assuming a time- and composition-dependent density, see Section 2.2.2) versus the measured total particle volume concentration by a SMPS at Sub SW before (left) and after (right) the scaling of all AMS-species by a factor of 1.3. Data shown are 15 min averages. 

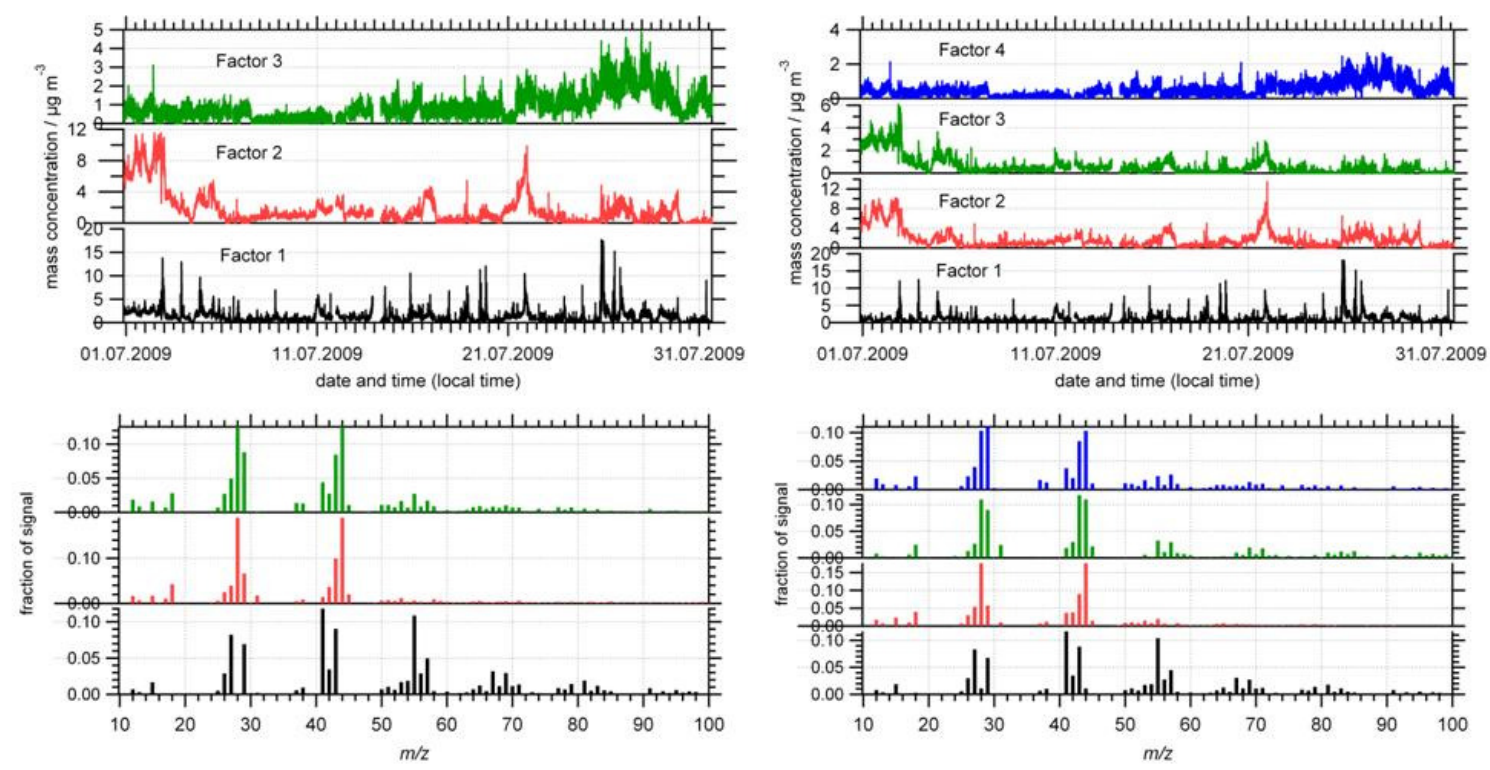

Figure S4. Time series and mass spectra of PMF three- and four-factor solution for Sub NE. Factor 3 in the three-factor solution is driven by instrumental noise and also present in the four-factor solution, where additionally factor 2 of the three-factor solution is being split up into factors 2 and 3.
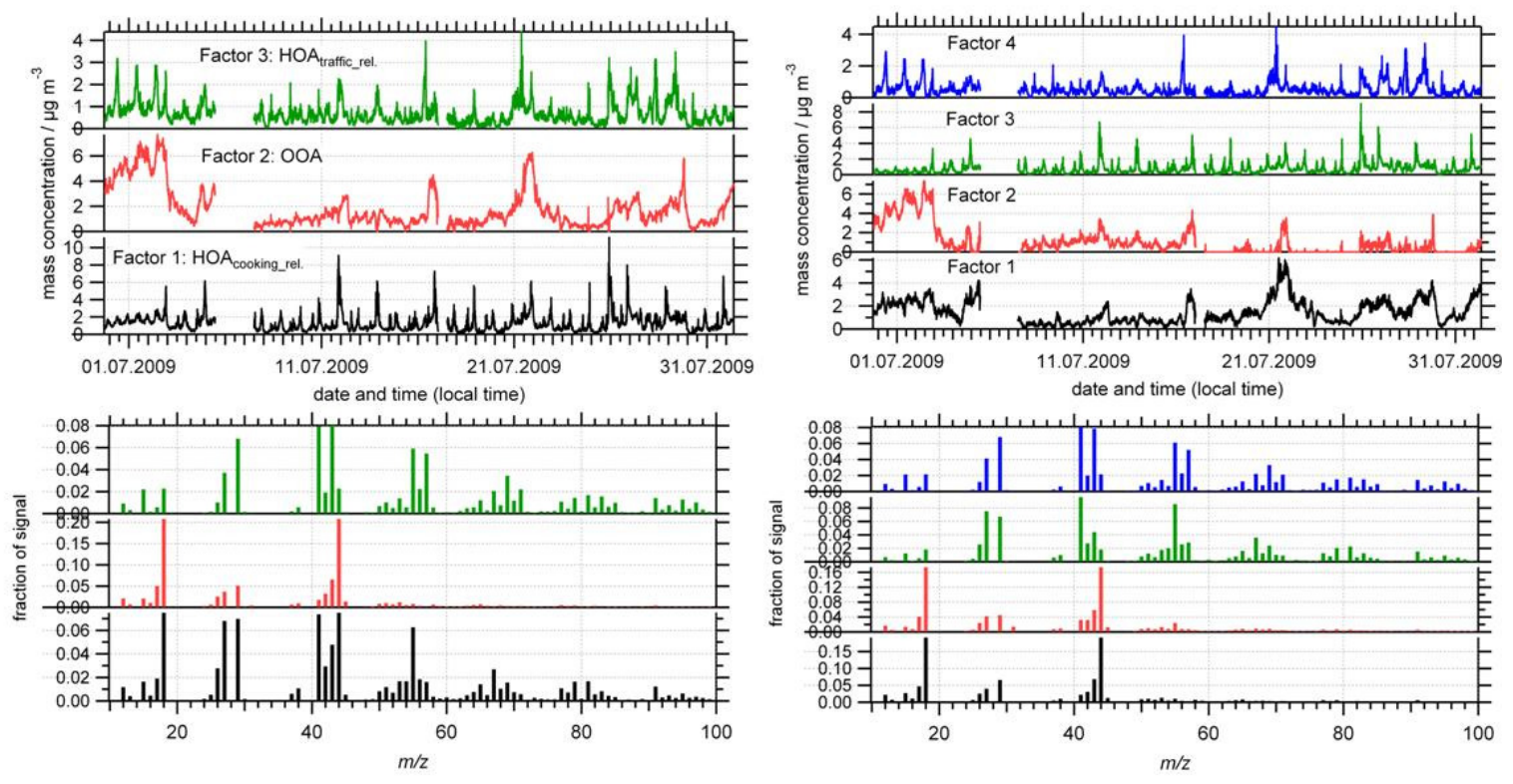

Figure S5. Time series and mass spectra of PMF three- and four-factor solution for the Downtown site. The factors of the three-factor solution represent two HOA factors $\left(\mathrm{HOA}_{\text {traffic_rel. }}\right.$ and $\left.\mathrm{HOA}_{\text {cooking_rel. }}\right)$ and one OOA factor, as described in the main text. For the 
four-factor solution, fpeak $=0$ did not converge; therefore the fpeak $=-0.1$ solution is shown here. The OOA factor splits up into two factors (factor 1 and 2) in this solution.
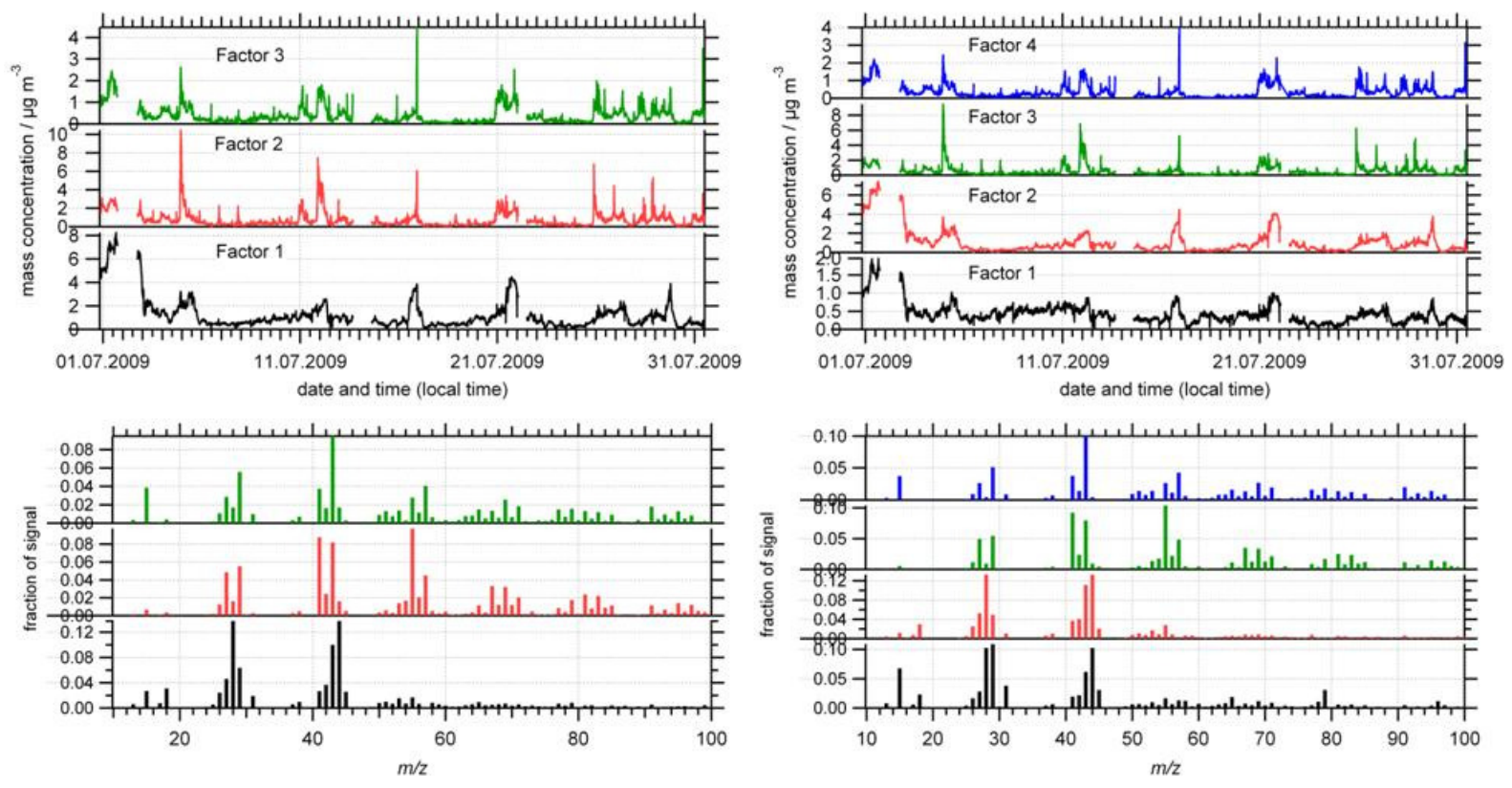

Figure S6. PMF three- and four-factor solutions for the Sub SW site. In the three-factor solution, splitting from the (two-factor solution) HOA factor is observed (factors 2 and 3), while for the four-factor solution, additionally the OOA factor splits (factors 1 and 2).

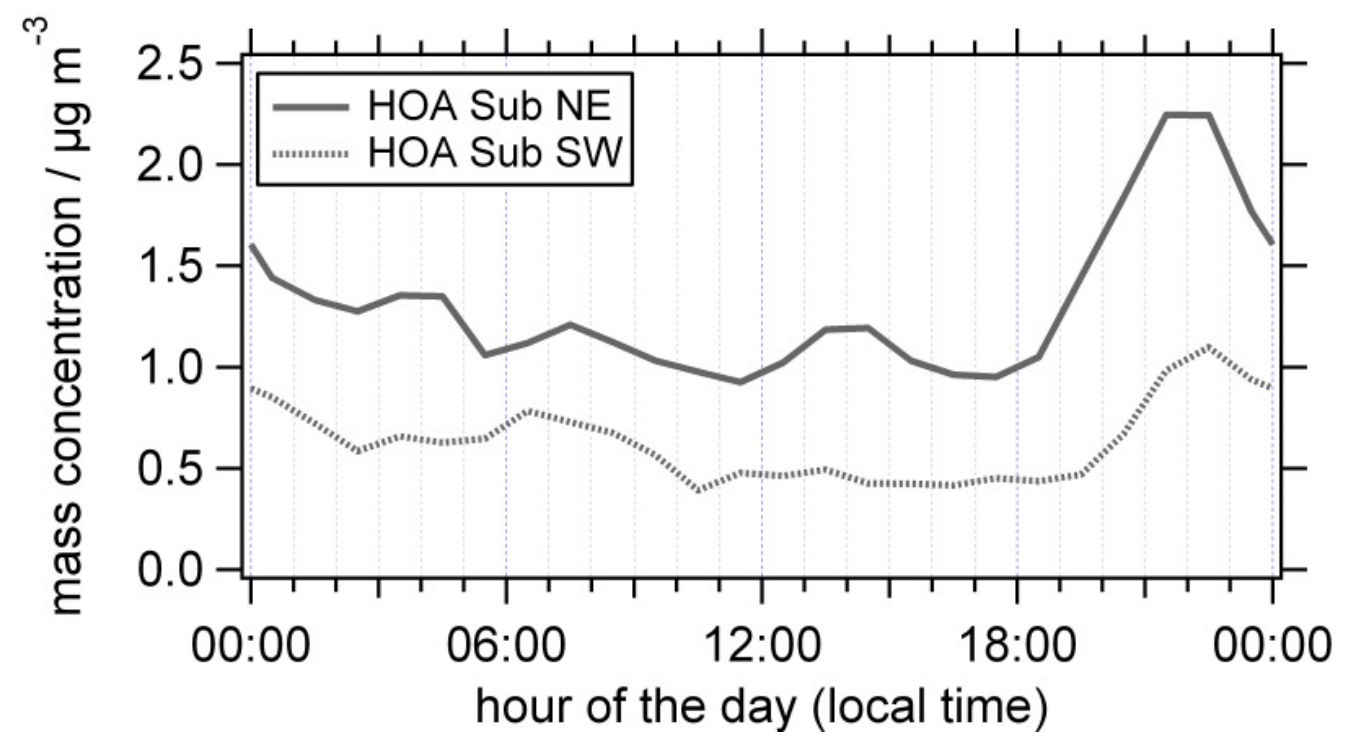

Figure S7. Diurnal cycles (hourly median values) of HOA at the Sub NE and Sub SW site. 


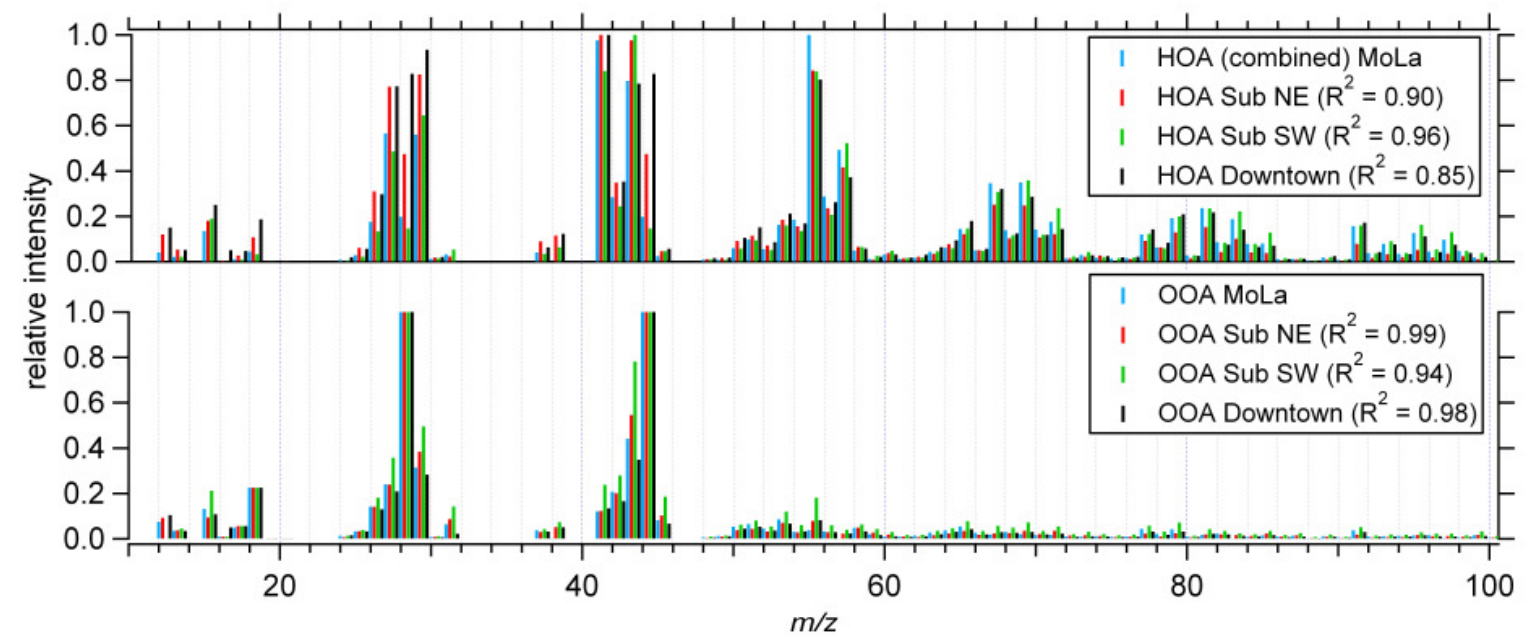

Figure S8. Comparison of the retrieved factor mass spectra for all sites and the Mobile Laboratory MoLa (the mass-weighted average of the mass spectra combined to HOA is shown here). For the Downtown AMS data analysis, a slightly different fragmentation patterns table was used than for the other AMSs, leading to different relative intensities at $m / z$ 's 17,18 , and 28. In this figure, the relative intensities at these $m / z$ 's therefore have been recalculated; for the correlations, those $\mathrm{m} / \mathrm{z}$ 's were not regarded. Given in brackets are Pearson's $\mathrm{R}^{2}$ values for the linear correlation with the respective MoLa AMS factor mass spectrum.

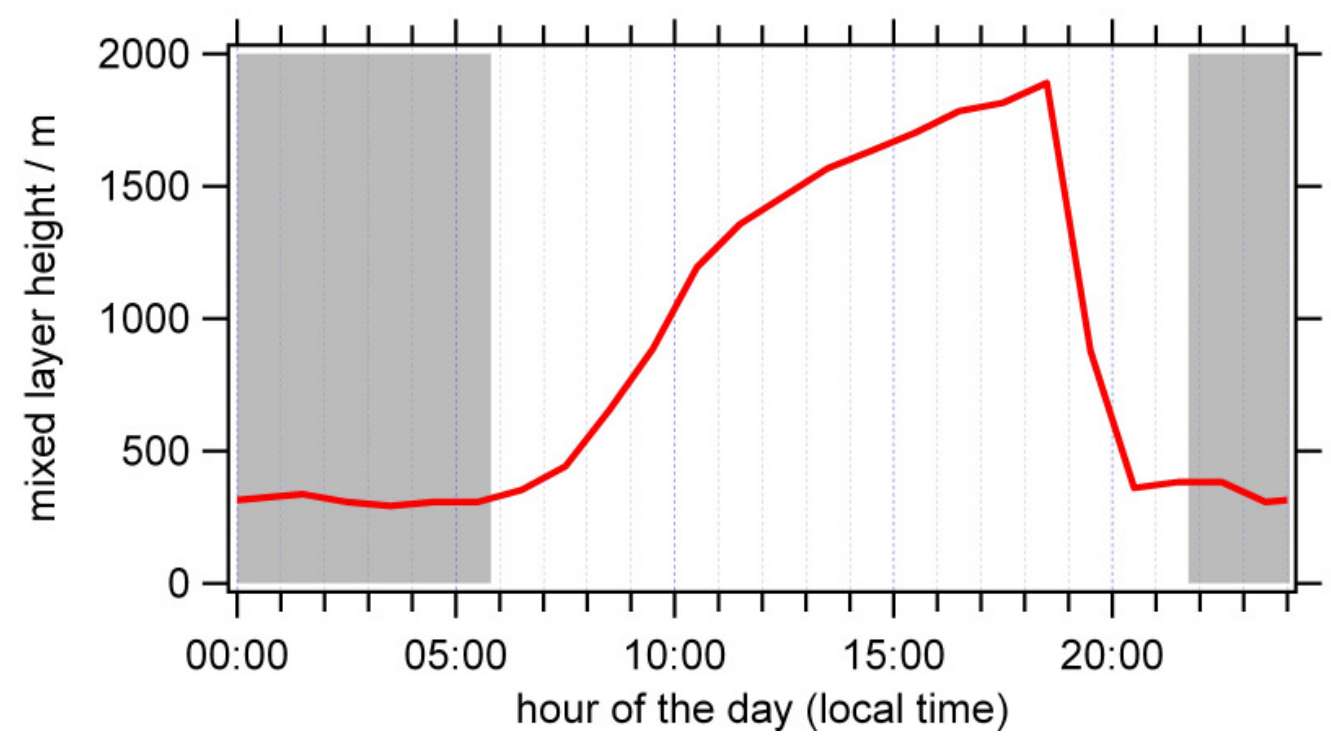

Figure S9. Diurnal cycle (hourly median values) of the mixed layer height retrieved from LIDAR measurements at Sub SW. The time period between sunset and sunrise is shaded in grey. 


\section{S1 Change of size distributions via collision rate}

The loss rate for particles of a given diameter $d_{p}$ within the measured polydisperse aerosol (i.e. the particle number size distribution measured with the EAS, representing time $t=0 \mathrm{~s}$ of the calculation) by collision with the available surface density was estimated using the equation

$$
N(t)=N_{0} \exp \left(-\frac{1}{4} \cdot \bar{c} \cdot S \cdot t\right)
$$

derived from the theoretical collision rate of the particles (Hinds, 1999). $N_{0}$ is the number concentration of particles with a certain diameter $d_{p}$ at $t=0 \mathrm{~s}, N(t)$ is their number concentration at time $t, S$ is the available surface density (integrated over all particle sizes), and $\bar{c}$ the mean velocity of the particles with diameter $d_{p}$. According to the kinetic gas theory, $\bar{c}$ can be written as:

$$
\bar{c}=\sqrt{\frac{8 k_{B} T}{\pi \cdot m}}
$$

$k_{B}$ is the Boltzmann constant $\left(1.38 \mathrm{e}-23 \mathrm{~J} \mathrm{~K}^{-1}\right), T$ the temperature (here we assume $20^{\circ} \mathrm{C}$, or $293 \mathrm{~K}$ ), and $m$ the mass of the individual particles with diameter $d_{p}$. This mass is estimated as that of a solid sphere with diameter $d_{p}$ and with a density of $1 \mathrm{~g} \mathrm{~cm}^{-3}$.

For the following calculations, the available surface density $S$ was calculated by integrating the surface distribution $\mathrm{d} S / \mathrm{d} \log d_{p}$, which was calculated from the number size distribution $\mathrm{d} N / \mathrm{d} \log d_{p}$ measured with the EAS for $t=0 \mathrm{~s}$. The particle diameter $d_{p}$ was chosen according to the maximum of the nucleation mode in the number size distribution measured with the EAS for $t=0 \mathrm{~s}$. 


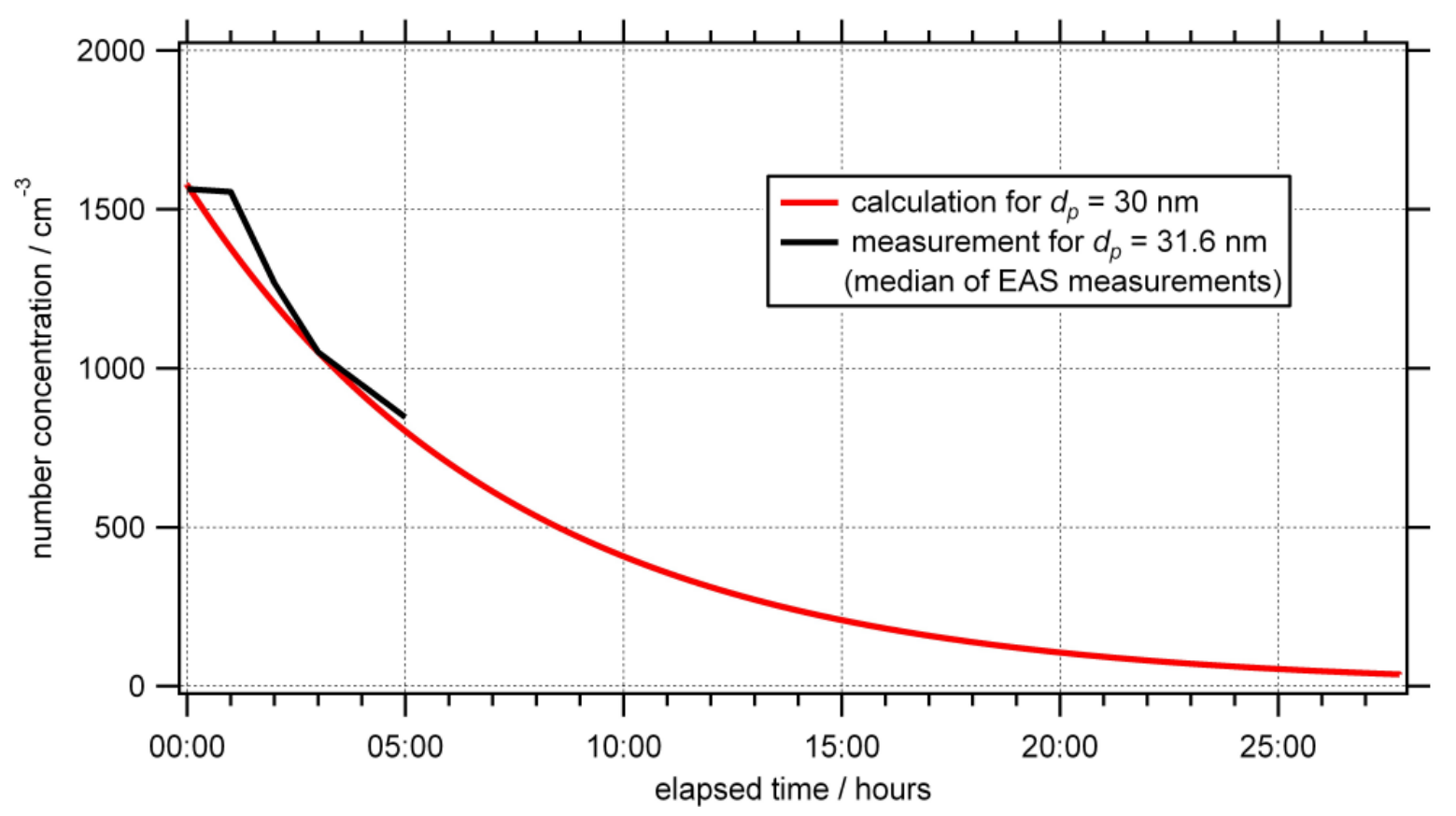

Figure S10. Measured number concentration of particles with $d_{p}=31.6 \mathrm{~nm}$ from the median diurnal cycle measured with the EAS ( $t=0 \mathrm{~s}$ is the hour between midnight and $1 \mathrm{am}$ ); and calculated number concentration of particles with $d_{p}=30 \mathrm{~nm}$ that are lost by collision with the available surface density $S=176 \mu \mathrm{m}^{2} \mathrm{~cm}^{-3}$ over time (starting from the measured number size distribution at $t=0 \mathrm{~s}$ with the number concentration of this particle size of $1577 \mathrm{~cm}^{-3}$ ). Theory and observations agree within $5 \%$ (linear regression through zero of measured versus predicted number concentrations: slope $\mathrm{m}=1.04$, Pearson's $\mathrm{R}^{2}=0.95$ ). 


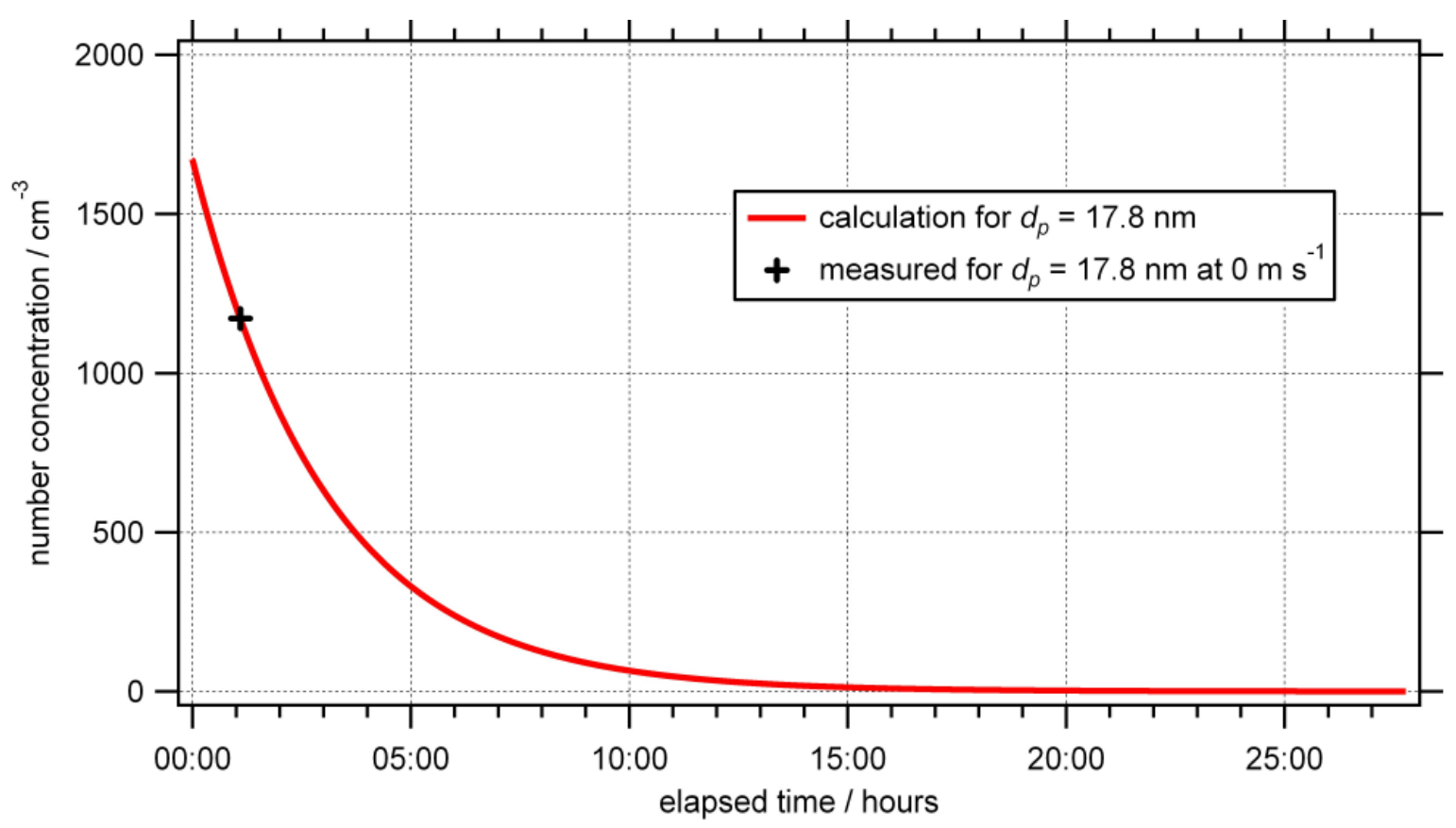

Figure S11. Calculated number concentration of particles with $d_{p}=17.8 \mathrm{~nm}$ from a starting number concentration of these particles of $1670 \mathrm{~cm}^{-3}$ as measured during periods with wind speed of $0.44 \mathrm{~m} \mathrm{~s}^{-1}$ and a surface area $S=193 \mu \mathrm{m}^{2} \mathrm{~cm}^{-3}$ as calculated from the same particle number size distribution. The encountered number concentration of $1171 \mathrm{~cm}^{-3}$ at the same particle diameter during calm periods (wind speed of $0 \mathrm{~m} \mathrm{~s}^{-1}$ ) is marked. From this calculation it can be estimated that the nucleation mode of the particle number size distribution as measured during wind speeds of $0.44 \mathrm{~m} \mathrm{~s}^{-1}$ can change due to coagulation with larger particles within about one hour to the one encountered during calm periods. 


\section{References}

Aiken, A. C., DeCarlo, P. F., Kroll, J. H., Worsnop, D. R., Huffman, J. A., Docherty, K. S., Ulbrich, I. M., Mohr, C., Kimmel, J. R., Sueper, D., Sun, Y., Zhang, Q., Trimborn, A., Northway, M., Ziemann, P. J., Canagaratna, M. R., Onasch, T. B., Alfarra, M. R., Prevot, A. S. H., Dommen, J., Duplissy, J., Metzger, A., Baltensperger, U., and Jimenez, J. L.: O/C and OM/OC Ratios of Primary, Secondary, and Ambient Organic Aerosols with High-Resolution Time-of-Flight Aerosol Mass Spectrometry, Environ. Sci. Technol., 42, 4478-4485, 10.1021/es703009q, 2008.

Allan, J. D., Delia, A. E., Coe, H., Bower, K. N., Alfarra, M. R., Jimenez, J. L., Middlebrook, A. M., Drewnick, F., Onasch, T. B., Canagaratna, M. R., Jayne, J. T., and Worsnop, D. R.: A generalised method for the extraction of chemically resolved mass spectra from Aerodyne aerosol mass spectrometer data, J. Aerosol. Sci., 35, 909-922, 10.1016/j.jaerosci.2004.02.007, 2004.

Allan, J. D., Williams, P. I., Morgan, W. T., Martin, C. L., Flynn, M. J., Lee, J., Nemitz, E., Phillips, G. J., Gallagher, M. W., and Coe, H.: Contributions from transport, solid fuel burning and cooking to primary organic aerosols in two UK cities, Atmos. Chem. Phys., 10, 647-668, 10.5194/acp-10-647-2010, 2010.

He, L.-Y., Lin, Y., Huang, X.-F., Guo, S., Xue, L., Su, Q., Hu, M., Luan, S.-J., and Zhang, Y.-H.: Characterization of high-resolution aerosol mass spectra of primary organic aerosol emissions from Chinese cooking and biomass burning, Atmos. Chem. Phys., 10, 1153511543, 10.5194/acp-10-11535-2010, 2010.

Hinds, W. C.: Aerosol technology: properties, behavior, and measurement of airborne particles, $2^{\text {nd }}$ ed., John Wiley \& Sons, Inc., New York, 1999.

Ulbrich, I. M., Canagaratna, M. R., Zhang, Q., Worsnop, D. R., and Jimenez, J. L.: Interpretation of organic components from Positive Matrix Factorization of aerosol mass spectrometric data, Atmos. Chem. Phys., 9, 2891-2918, 10.5194/acp-9-2891-2009, 2009. 